\title{
NK/T-cell lymphomas in children
}

\author{
Catherine Lai and Kieron Dunleavy \\ Center for Cancer Research, National Cancer Institute, Bethesda, MD
}

\begin{abstract}
In children, $\mathrm{T}$ and NK-cell lymphomas are uncommon in Western Countries. While there has been significant experience treating T-cell lymphoblastic lymphoma (T-LBL) and anaplastic large cell lymphoma (ALCL), other subtypes are very rarely encountered and there are no standard approaches to their management. There are many challenges in defining optimal therapy for many of these diseases but recent progress in elucidating their biology has led to new molecular insights and identified interesting targets for novel drug discovery. In this review, we discuss these disorders in children, how they are approached therapeutically and what lies on the horizon with respect to novel treatment approaches.
\end{abstract}

\section{Keywords}

T-lymphoblastic lymphoma; T-LBL; anaplastic large cell lymphoma; ALCL; ALK; PTCL-NOS; angioimmunoblastic T-cell lymphoma; AITL; NOTCH1; mTOR; CD30

\section{Introduction}

Pediatric T-cell and NK cell lymphomas are rarely encountered and are much more uncommon than B-cell lymphomas in this population (NHL). Their incidence is highest in Asian and Latin American countries and they are relatively uncommon in Western countries. The histological spectrum of NK/T cell lymphomas in children is very different from that in adults and in the former population, T-cell lymphoblastic lymphoma (T-LBL) and anaplastic large cell lymphoma (ALCL) are the most frequent subtypes. More rare subtypes that are uncommonly seen include peripheral T-cell lymphoma - not otherwise specified (PTCLNOS), extra-nodal nasal type NK/T-cell lymphoma, subcutaneous panniculitis-like T cell lymphoma, enteropathy-associated T-cell lymphoma and angioimmunoblastic T-cell lymphoma (AITL). Of these more rare types, PTCL-NOS is the most common, with the other lymphomas being infrequently encountered as case reports or in very small cohorts. As is the case with T-cell lymphomas in adults, the molecular biology of these diseases is for the most part poorly understood, but ALK positive ALCL is an exception to this ${ }^{1,2}$.

An accurate histological diagnosis is imperative and the most important test is a properly evaluated and technically adequate tissue biopsy. These cases should be diagnosed by an expert hematopathologist, who is familiar with the potential pitfalls and nuances of

Corresponding author: Kieron Dunleavy, National Cancer Institute, Building 10, Rm 12N226, 10 Center Drive, Bethesda, MD 20892, USA, Tel: +1-301-435-1007, Fax: +1- 301-480-1105, dunleavk@ mail.nih.gov.

Publisher's Disclaimer: This is a PDF file of an unedited manuscript that has been accepted for publication. As a service to our customers we are providing this early version of the manuscript. The manuscript will undergo copyediting, typesetting, and review of the resulting proof before it is published in its final citable form. Please note that during the production process errors may be discovered which could affect the content, and all legal disclaimers that apply to the journal pertain.

Conflict of interest: The authors have no relevant disclosures or conflicts of interest. 
lymphoma diagnosis. Benign lymph node enlargement, particularly of head and neck nodes, is common in children and therefore history, clinical presentation and sites of involvement are important for the pathologist to note.

This review will focus mostly on T-LBL, ALCL and PTCL-NOS with a brief discussion of other NK/T-cell lymphomas.

\section{T-cell lymphoblastic lymphoma (T-LBL) Pathogenesis}

T-LBL, arising from precursor $\mathrm{T}$ lymphoblasts, is the most common pediatric T-cell lymphoma and accounts for approximately $90 \%$ of all lymphoblastic lymphomas ${ }^{1}$. It is most frequently seen in adolescent males and the molecular features of T-LBL are similar to those of acute lymphoblastic leukemia (ALL) - the two make up a disease spectrum and are distinguished based on percentage of bone marrow involvement. For the purposes of treatment, a cutoff of greater than $25 \%$ bone marrow blasts is used as the threshold for defining leukemia ${ }^{1}$. In T-LBL, lymphoblasts are typically of small or medium size with scanty cytoplasm, condensed nuclear chromatin, round or convoluted nuclei and with small or indistinct nucleoli. Some lymphoblasts are characterized by coarse azurophilic granules. These blasts are usually TDT positive. They commonly express CD3 and CD7 whereas CD1a, CD2, CD4, CD5 and CD8 are variably expressed. CD10 may also be positive ${ }^{1}$. There is a paucity of literature regarding typical chromosomal aberrations for T-LBL but they most commonly involve T-cell receptor (TCR) gene loci at chromosome $14 \mathrm{q} 11$ or $7 \mathrm{q} 34^{3}$. These translocations lead to juxtaposition of an oncogenic partner gene with the regulatory region of one of the TCR loci and this leads to a dysregulation of transcription of the partner gene. Various other aberrations may also occur.

\section{Clinical Features}

Clinical features are similar to acute lymphoblastic leukemia (ALL) and T-LBL usually presents with a mediastinal mass and often with symptoms of airway compression. Patients may present with superior vena cava (SVC) syndrome with swelling of the face and neck. Pleural effusions are common. Skin, bone, gonadal or central nervous system involvement may sometimes occur. Staging involves imaging with computed tomography, bone marrow evaluation and lumbar puncture. T-LBL in children is most commonly staged using the Murphy Classification. ${ }^{4,5}$

\section{Prognosis}

Current treatment paradigms for T lymphoblastic lymphoma are based on ALL regimens ${ }^{6-9}$. For pediatric patients long term overall survivals in the range of $80-95 \%$ can be achieved with current strategies - these are superior to outcomes in adults ${ }^{6,7,10-12}$. Gender has not been shown to have a prognostic impact in pediatric T-LBL and CNS disease confers a worse prognosis 6,13 . Minimal disease in the bone marrow, detected by flow cytometry, has been shown to be associated with a worse outcome and the Children's Oncology Group (COG) is currently investigating risk stratification of T-LBL patients based on the presence of minimal disease in the bone marrow at diagnosis with high risk patients receiving additional therapy ${ }^{14}$.

\section{Treatment}

Patients with T-LBL are at high risk of tumor lysis syndrome (TLS) and this should be anticipated and hydration, allopurionol and/or rasburicase administered as indicated to patients who are at risk ${ }^{12,15}$. Standard treatments for T-LBL have been modified from ALL protocols (Table 1) and are typically comprised of induction, consolidation, re- 
intensification, and maintenance treatment phases ${ }^{16}$. One of the first regimens that demonstrated good efficacy in this disease was called LSA2-L2 and constituted a 10-drug regimen with radiation administered to sites of bulky disease ${ }^{17}$. In a long-term follow-up of the regimen, patients with disseminated T-LBL had 5-year event-free and overall survivals of $64 \%$ and $67 \%$ respectively and these were significantly better than for similar patients who received a 4-drug regimen - COMP - where the EFS and OS were $35 \%$ and $45 \%$ at 5 years.

Thereafter, the Berlin-Frankfurt-Munster group created BFM-90 using a treatment regimen similar to ALL protocols (without local radiotherapy) at that time with treatment duration of 24 months. The majority of patients had advanced stage disease and received prophylactic cranial radiotherapy - with this approach, the five year EFS was $90 \%$ for all patients 6 . Subsequent studies in T-LBL investigated similar regimens to either LSA2-L2 or BFM-90 but attempted to remove prophylactic cranial radiotherapy. BFM-95, for example, tailored treatment according to response to induction chemotherapy in CNS negative stage III and IV disease and omitted prophylactic cranial radiotherapy and local radiotherapy - the 5-year event-free survival was $82 \%$ with this approach ${ }^{18}$. The EORTC Children's Leukemia Group (CLG) 58881 study also omitted local and cranial radiation in all stages of disease and reported an EFS of $78 \%$ and OS of $86 \%$ at 6 years ${ }^{9}$. Another study (St. Jude NHL13) intensified intrathecal therapy and did not include prophylactic cranial radiation in patients with stage III and IV disease and reported a 5 year EFS of 83\%, again supporting the noninclusion of radiation ${ }^{7}$. These studies support the current standard use of ALL type regimens with the omission of CRT in most patients and CNS chemotherapy prophylaxis, even in the presence of advanced stage disease.

Relapses of T-LBL typically occur within a year of treatment ${ }^{19}$. Most patients are treated with intense re-induction followed by autologous or allogeneic stem cell transplantation but most studies that have been done are small (less than 10 patients) ${ }^{20-22}$. In terms of future strategies, NOTCH1 activation appears to be important in the pathogenesis of T-ALL and Tlymphoblastic lymphoma and strategies that target NOTCH1 upregulation are being tested in vitro ${ }^{23-26}$. mTOR pathways also appear to be important in these diseases and strategies that target mTOR are under investigation ${ }^{27,28}$. Pim protein kinase small molecule inhibitors are also under investigation ${ }^{29}$.

\section{Anaplastic large cell lymphoma}

\section{Pathogenesis}

Most ALCLs that occur in pediatric populations are ALK positive and ALK positive ALCL represents $10-20 \%$ of childhood lymphomas ${ }^{30,31}$. ALK positive cases are most commonly characterized by a translocation $\mathrm{t}(2 ; 5)(\mathrm{p} 23 ; \mathrm{q} 35)$ between the ALK gene on chromosome 2 and the nucleophosmin (NPM) gene on chromosome $5^{32-34}$. While the $t(2: 5)$ translocation is found in over $80 \%$ of cases of ALK positive ALCL, variant translocations involving ALK and other partner genes on various chromosomes can also occur ${ }^{35,36}$. The transforming NPM-ALK fusion protein that results encodes a tyrosine kinase receptor, resulting ultimately in the constitutive activation of anaplastic lymphoma kinase and its downstream pathways ${ }^{37}$. ALK can be detected by immunohistochemistry and while in the majority of cases with the classical $t(2 ; 5) / \mathrm{NPM}$-ALK translocation, ALK staining is both cytoplasmic and nuclear, it may be membranous or cytoplasmic in variant cases ${ }^{32}$.

The histopathology of ALCL in pediatrics is similar to that in adults and the vast majority of pediatric cases are ALK protein positive. ALCL was first described by Stein and colleagues in 1985, when he reported the expression of the CD30 antigen in a group of NHLs with anaplastic large cells that had a predilection for young patients ${ }^{38}$. Morphologically, ALCL is 
characterized by large pleomorphic cells (referred to as 'hallmark' cells) with eccentrically located and horse-shoe shaped nuclei that express the CD30 antigen and in most cases the epithelial membrane antigen (EMA) ${ }^{1}$. As discussed above, immunohistochemistry is used to detect ALK positivity.

\section{Clinical Presenation}

The spectrum of clinical presentation is broad including nodal, extranodal, and leukemic diseases and may be associated with hemophagocytosis, fevers and rashes. Children often have fever and weight loss and the majority of cases present with advanced stage disease and often involvement of the lung, skin, soft tissue or bone ${ }^{39}$. Patients often present with constitutional symptoms. Involvement of the central nervous system is very rare at diagnosis ${ }^{39}$. Patients who have the small cell variant of ALK positive ALCL may present with peripheral blood involvement. ${ }^{40}$ Most patients present with stage III or IV disease but respond to anthracycline-based chemotherapy. Not surprisingly, patients with stage I/II disease do better ${ }^{41}$. In those who relapse, salvage chemotherapy is often effective. As with adults, patients with ALK negative ALCL have a worse prognosis but ALK negative cases are rarely encountered in pediatric populations ${ }^{42}$.

\section{Prognosis}

The outcome for most pediatric patients with ALK positive ALCL is good with survivals ranging from $70 \%$ to $90 \%$ in most series ${ }^{17,39,41,43-47}$. As with other pediatric lymphomas, patients with early stage disease have a better outcome than those with advanced stage disease. ALK positive cases have a better outcome than ALK negative cases but there is no difference in prognosis between cases that have the classic NPM-ALK translocation compared to cases with variant translocations. Bone marrow involvement at diagnosis has been shown to be associated with a worse outcome.

\section{Treatment}

Though there are many successful treatment strategies for pediatric ALCL, the optimal therapy has not yet been defined. As is the case in the treatment of adults with ALCL, anthracycline-based regimens that are used for aggressive B-cell lymphoma are typically used (Table 2$)^{48}$. In terms of studies that have been done in pediatric ALCL, Seidemann and colleagues enrolled 89 patients with ALCL in the BFM-90 trial ${ }^{39}$. Patients were stratified based on their stage into three cohorts and treated with escalating doses of therapy according to the stage of disease at presentation. The 5 year event free survival was $76 \%$ for all patients and when broken down according to stage, it was $100 \%$ for resected stage I or II disease, $73 \%$ for non-resected stage II or stage III disease and 79\% for stage IV disease. The NHL-BFM 90 protocol was attractive as it was associated with lower toxicity than many other pediatric protocols ${ }^{44,49,50}$. Prior to this, the St. Jude's group reported a $75 \%$ EFS in patients with limited stage CD30 positive large cell lymphoma following 3 cycles of CHOP chemotherapy, with or without maintenance therapy ${ }^{41}$.

Various strategies for advanced stage ALCL have achieved EFS rates between $65 \%$ and 75\%. The Children's Cancer Group treated 86 pediatric non-localized ALCL patients with a multi-agent intensive chemotherapy regimen (CCG-5941) that was followed by maintenance therapy ${ }^{46}$. They reported a $68 \%$ EFS at 5 years and this was similar to previous regimens but their approach was associated with much more toxicity. The Pediatric Oncology Group (POG) performed a randomized study that assessed the addition of intermediate dose methotrexate and high dose cytarabine in the maintenance phase of the APO regimen in patients with advanced stage ALCL and they did not demonstrate a better EFS than with APO alone ${ }^{43}$. The European intergroup ALCL99 trial - based on the NHL-BFM-90 study tested a less toxic regimen with high dose MTX and no IT therapy (compared to the 
BFM-90 study) and demonstrated a similar EFS with this - they concluded that the methotrexate schedule of BFM90 could be safely replaced with a less toxic schedule ${ }^{44,45}$. This study also included a second randomization to limited versus prolonged vinblastine. At 2 years follow-up there was no difference in outcome between the two groups.

Recurrent pediatric ALCL is typically very chemosensitive and should be approached aggressively. Various treatment approaches have been investigated that have ranged from single agent vinblastine (which is highly effective as a single agent) to fully ablative therapy followed by autologous or allogeneic transplantation ${ }^{51,52}$. Albeit limited experience, both autologous and allogeneic transplantation have been used successfully and are strategies that should be considered for patients in first relapse ${ }^{53-55}$. In terms of novel agents for ALCL, brentuximab vedotin - an antibody-drug conjugate directed against CD30 - has been used successfully in adults with relapsed ALCL but has not been tested in children ${ }^{56-58}$. The ALK inhibitor - crizotinib - has also shown promise in early trials ${ }^{59,60}$.

\section{Peripheral T-cell lymphoma}

PTCL-NOS is the second most common PTCL in children after ALCL but is rarely encountered and not well studied in this population. Unlike ALCL, the molecular biology of this disease has not been well elucidated and is poorly understood ${ }^{2}$. Presentations are highly variable and manifestations of disease (such as rash, fever or irritability) can be very nonspecific. Patients often exhibit generalized lymphadenopathy and B symptoms occur about half the time but do not correlate with stage. As with ALCL, patients with stage I or II disease have a better outcome than patients with higher stage disease but the outcome is significantly inferior to that of children with ALCL ${ }^{61,62}$.

Morphologically, PTCL-NOS is characterized by a mixture of small and large atypical lymphoid cells that express CD3 and either CD4 or CD8. CD30 is variably expressed $^{1,63}$.There is often an inflammatory background of plasma cells, eosinophils and small lymphocytes seen.

Treatment strategies for pediatric PTCL-NOS are very varied but these diseases are typically treated with anthracycline-based (CHOP-like) therapy, with or without the addition of radiotherapy ${ }^{16,61}$. There have been very limited studies done, looking specifically at PTCLNOS in pediatric populations, due to the rarity of the disease ${ }^{61}$. The experience is limited to very small cohorts and retrospective series and the outcome of children with PTCL-NOS is unknown due to these limitations. In adults, the treatment of PTCL-NOS is controversial and many novel agents are being studied but the outcome is significantly inferior to that of patients with ALCL (both ALK positive and ALK negative) ${ }^{64,65}$. Similarly, the management of these diseases at relapse is controversial and aggressive approaches such as autologous and allogeneic bone marrow transplantation have had variable results ${ }^{66,67}$.

\section{Other mature T- and NK-cell neoplasms}

Other $\mathrm{T}$ and $\mathrm{NK}$ cell lymphomas are extremely rare in children and are more common in Asia. Of the other mature T and NK-cell lymphomas listed in the WHO Classification, extra nodal NK/T cell lymphoma, hepatosplenic gamma-delta T-cell lymphoma, subcutaneous panniculitis-like T-cell lymphoma, and angioimmunoblastic T-cell lymphoma are occasionally observed in children. Extra nodal NK/T cell lymphomas are typically positive for EBV and express CD56. Clinical presentation in children is similar to that of adults - the disease tends to have a male predominance, most cases are diagnosed at an early stage and patients often have $\mathrm{B}$ symptoms and an elevated $\mathrm{LDH}^{68}$. The most common extranodal NK/ $\mathrm{T}$ cell lymphoma is the nasal subtype and at presentation, the tumor may cause bony destruction around the sinuses and nasal septum or present with airway obstruction ${ }^{69}$. The 
prognosis does not appear to be affected by characteristics such as age, sex or B symptoms. Extranasal NK disease has a much worse prognosis than the common nasal type ${ }^{64}$.

Other T-cell lymphomas are very rarely encountered in children. Hepatosplenic gammadelta T-cell lymphoma is a very aggressive lymphoma of young adults with a predilection for males. It typically presents with massive hepatosplenomegaly and bone marrow involvement is common - involvement of lymph nodes is uncommon. Cases sometimes arise in patients who are receiving chronic immunosuppression such as patients with inflammatory bowel disease who are receiving infliximab ${ }^{70}$. Karyotypic studies show isochromosome $7 \mathrm{q}^{71}$. The prognosis of this disease is extremely poor with standard therapy and approaches such as allogeneic transplantation should be considered ${ }^{72}$. Subcutaneous panniculitis-like T-cell lymphoma, as the name implies, presents with subcutaneous nodules with atypical T-cell infiltrations. The disease is usually localized to the skin with infrequent organ or lymph node involvement. The course is usually indolent but patients can occasionally present with symptoms of hemophagocytic syndrome ${ }^{73}$. Characteristic features of angioimmunoblastic T-cell lymphoma include generalized lymphadenopathy, hepatosplenomegaly, skin rash and constitutional symptoms. Patients may have signs of B cell hyperactivity that include polyclonal hypergammaglobulinemia and other hematological abnormalities (such as Coombs-positive hemolytic anemia). At the same time, patients exhibit evidence of immunodeficiency and opportunistic infections frequently occur with many patients succumbing to the infectious complications of AILT, rather than progressive lymphoma.

\section{References}

1. Swerdlow, SH.; Campo, E.; Harris, NL., et al. Lyon: IARC; 2008. WHO Classification of Tumours of Haematopoietic and Lymphoid Tissues.

2. Dunleavy K, Piekarz RL, Zain J, et al. New strategies in peripheral T-cell lymphoma: understanding tumor biology and developing novel therapies. Clin Cancer Res. 2010 Dec 1; 16(23):5608-5617. [PubMed: 21138864]

3. Graux C, Cools J, Michaux L, Vandenberghe P, Hagemeijer A. Cytogenetics and molecular genetics of T-cell acute lymphoblastic leukemia: from thymocyte to lymphoblast. Leukemia. 2006 Sep; 20(9):1496-1510. [PubMed: 16826225]

4. Murphy SB, Bowman WP, Abromowitch M, et al. Results of treatment of advanced-stage Burkitt's lymphoma and B cell (SIg+) acute lymphoblastic leukemia with high-dose fractionated cyclophosphamide and coordinated high-dose methotrexate and cytarabine. J Clin Oncol. 1986 Dec; 4(12):1732-1739. [PubMed: 3491184]

5. Murphy SB. Childhood non-Hodgkin's lymphoma. N Engl J Med. 1978 Dec 28; 299(26):14461448. [PubMed: 362210]

6. Reiter A, Schrappe M, Ludwig WD, et al. Intensive ALL-type therapy without local radiotherapy provides a $90 \%$ event-free survival for children with T-cell lymphoblastic lymphoma: a BFM group report. Blood. 2000 Jan 15; 95(2):416-421. [PubMed: 10627444]

7. Sandlund JT, Pui CH, Zhou Y, et al. Effective treatment of advanced-stage childhood lymphoblastic lymphoma without prophylactic cranial irradiation: results of St Jude NHL13 study. Leukemia. 2009 Jun; 23(6):1127-1130. [PubMed: 19194463]

8. Pillon M, Piglione M, Garaventa A, et al. Long-term results of AIEOP LNH-92 protocol for the treatment of pediatric lymphoblastic lymphoma: a report of the Italian Association of Pediatric Hematology and Oncology. Pediatr Blood Cancer. 2009 Dec; 53(6):953-959. [PubMed: 19621432]

9. Uyttebroeck A, Suciu S, Laureys G, et al. Treatment of childhood T-cell lymphoblastic lymphoma according to the strategy for acute lymphoblastic leukaemia, without radiotherapy: long term results of the EORTC CLG 58881 trial. Eur J Cancer. 2008 Apr; 44(6):840-846. [PubMed: 18342502]

10. Reiter A, Schrappe M, Ludwig WD, et al. Favorable outcome of B-cell acute lymphoblastic leukemia in childhood: a report of three consecutive studies of the BFM group. Blood. 1992 Nov 15; 80(10):2471-2478. [PubMed: 1421370] 
11. Termuhlen AM, Smith LM, Perkins SL, et al. Outcome of newly diagnosed children and adolescents with localized lymphoblastic lymphoma treated on Children's Oncology Group trial A5971: a report from the Children's Oncology Group. Pediatr Blood Cancer. 2012 Dec 15; 59(7): 1229-1233. [PubMed: 22488718]

12. Hoelzer D, Gokbuget N, Digel W, et al. Outcome of adult patients with T-lymphoblastic lymphoma treated according to protocols for acute lymphoblastic leukemia. Blood. 2002 Jun 15; 99(12):4379-4385. [PubMed: 12036865]

13. Cairo MS, Gerrard M, Sposto R, et al. Results of a randomized international study of high-risk central nervous system B non-Hodgkin lymphoma and B acute lymphoblastic leukemia in children and adolescents. Blood. 2007 Apr 1; 109(7):2736-2743. [PubMed: 17138821]

14. Coustan-Smith E, Sandlund JT, Perkins SL, et al. Minimal disseminated disease in childhood Tcell lymphoblastic lymphoma: a report from the children's oncology group. J Clin Oncol. 2009 Jul 20; 27(21):3533-3539. [PubMed: 19546402]

15. Hochberg J, Cairo MS. Tumor lysis syndrome: current perspective. Haematologica. 2008 Jan; 93(1):9-13. [PubMed: 18166779]

16. Link MP, Shuster JJ, Donaldson SS, Berard CW, Murphy SB. Treatment of children and young adults with early-stage non-Hodgkin's lymphoma. N Engl J Med. 1997 Oct 30; 337(18):1259_ 1266. [PubMed: 9345074]

17. Anderson JR, Jenkin RD, Wilson JF, et al. Long-term follow-up of patients treated with COMP or LSA2L2 therapy for childhood non-Hodgkin's lymphoma: a report of CCG-551 from the Childrens Cancer Group. J Clin Oncol. 1993 Jun; 11(6):1024-1032. [PubMed: 8501488]

18. Burkhardt B, Woessmann W, Zimmermann M, et al. Impact of cranial radiotherapy on central nervous system prophylaxis in children and adolescents with central nervous system-negative stage III or IV lymphoblastic lymphoma. J Clin Oncol. 2006 Jan 20; 24(3):491-499. [PubMed: 16421426]

19. Burkhardt B, Reiter A, Landmann E, et al. Poor outcome for children and adolescents with progressive disease or relapse of lymphoblastic lymphoma: a report from the berlin-frankfurtmuenster group. J Clin Oncol. 2009 Jul 10; 27(20):3363-3369. [PubMed: 19433688]

20. Hartmann O, Pein F, Beaujean F, et al. High-dose polychemotherapy with autologous bone marrow transplantation in children with relapsed lymphomas. J Clin Oncol. 1984 Sep; 2(9):979985. [PubMed: 6381657]

21. Mills W, Chopra R, McMillan A, Pearce R, Linch DC, Goldstone AH. BEAM chemotherapy and autologous bone marrow transplantation for patients with relapsed or refractory non-Hodgkin's lymphoma. J Clin Oncol. 1995 Mar; 13(3):588-595. [PubMed: 7884420]

22. Won SC, Han JW, Kwon SY, et al. Autologous peripheral blood stem cell transplantation in children with non-Hodgkin's lymphoma: A report from the Korean society of pediatric hematology-oncology. Ann Hematol. 2006 Nov; 85(11):787-794. [PubMed: 16932891]

23. Yamamoto K, Nakamachi Y, Yakushijin K, et al. A novel TRB@/NOTCH1 fusion gene in T-cell lymphoblastic lymphoma with t(7;9)(q34;q34). Eur J Haematol. 2013 Jan; 90(1):68-75. [PubMed: 23033986]

24. Callens C, Baleydier F, Lengline E, et al. Clinical impact of NOTCH1 and/or FBXW7 mutations, FLASH deletion, and TCR status in pediatric T-cell lymphoblastic lymphoma. J Clin Oncol. 2012 Jun 1; 30(16):1966-1973. [PubMed: 22547598]

25. Lin YW, Nichols RA, Letterio JJ, Aplan PD. Notch1 mutations are important for leukemic transformation in murine models of precursor-T leukemia/lymphoma. Blood. 2006 Mar 15; 107(6):2540-2543. [PubMed: 16282337]

26. Kindler T, Cornejo MG, Scholl C, et al. K-RasG12D-induced T-cell lymphoblastic lymphoma/ leukemias harbor Notch1 mutations and are sensitive to gamma-secretase inhibitors. Blood. 2008 Oct 15; 112(8):3373-3382. [PubMed: 18663146]

27. Evangelisti C, Ricci F, Tazzari P, et al. Targeted inhibition of mTORC1 and mTORC2 by activesite mTOR inhibitors has cytotoxic effects in T-cell acute lymphoblastic leukemia. Leukemia. 2011 May; 25(5):781-791. [PubMed: 21331075] 
28. Zhang C, Ryu YK, Chen TZ, Hall CP, Webster DR, Kang MH. Synergistic activity of rapamycin and dexamethasone in vitro and in vivo in acute lymphoblastic leukemia via cell-cycle arrest and apoptosis. Leuk Res. 2012 Mar; 36(3):342-349. [PubMed: 22137317]

29. Lin YW, Beharry ZM, Hill EG, et al. A small molecule inhibitor of Pim protein kinases blocks the growth of precursor T-cell lymphoblastic leukemia/lymphoma. Blood. 2010 Jan 28; 115(4):824833. [PubMed: 19965690]

30. Stein H, Foss HD, Durkop H, et al. CD30(+) anaplastic large cell lymphoma: a review of its histopathologic, genetic, and clinical features. Blood. 2000 Dec 1; 96(12):3681-3695. [PubMed: 11090048]

31. Shiota M, Nakamura S, Ichinohasama R, et al. Anaplastic large cell lymphomas expressing the novel chimeric protein p80NPM/ALK: a distinct clinicopathologic entity. Blood. 1995 Sep 1; 86(5):1954-1960. [PubMed: 7655022]

32. Swerdlow, S.; Campo, E.; Harris, N., et al. Lyon: IARC; 2008. WHO Classification of Tumours of Haematopoietic and Lymphoid Tissues.

33. Lamant L, Meggetto F, al Saati T, et al. High incidence of the $t(2 ; 5)(\mathrm{p} 23 ; \mathrm{q} 35)$ translocation in anaplastic large cell lymphoma and its lack of detection in Hodgkin's disease. Comparison of cytogenetic analysis, reverse transcriptase-polymerase chain reaction, and P-80 immunostaining. Blood. 1996 Jan 1; 87(1):284-291. [PubMed: 8547653]

34. Morris SW, Kirstein MN, Valentine MB, et al. Fusion of a kinase gene, ALK, to a nucleolar protein gene, NPM, in non-Hodgkin's lymphoma. Science. 1994 Mar 4; 263(5151):1281-1284. [PubMed: 8122112]

35. Falini B, Pileri S, Zinzani PL, et al. ALK+ lymphoma: clinico-pathological findings and outcome. Blood. 1999 Apr 15; 93(8):2697-2706. [PubMed: 10194450]

36. Falini B, Pulford K, Pucciarini A, et al. Lymphomas expressing ALK fusion protein(s) other than NPM-ALK. Blood. 1999 Nov 15; 94(10):3509-3515. [PubMed: 10552961]

37. Bischof D, Pulford K, Mason DY, Morris SW. Role of the nucleophosmin (NPM) portion of the non-Hodgkin's lymphoma-associated NPM-anaplastic lymphoma kinase fusion protein in oncogenesis. Mol Cell Biol. 1997 Apr; 17(4):2312-2325. [PubMed: 9121481]

38. Stein H, Mason DY, Gerdes J, et al. The expression of the Hodgkin's disease associated antigen $\mathrm{Ki}-1$ in reactive and neoplastic lymphoid tissue: evidence that Reed-Sternberg cells and histiocytic malignancies are derived from activated lymphoid cells. Blood. 1985 Oct; 66(4):848-858. [PubMed: 3876124]

39. Seidemann K, Tiemann M, Schrappe M, et al. Short-pulse B-non-Hodgkin lymphoma-type chemotherapy is efficacious treatment for pediatric anaplastic large cell lymphoma: a report of the Berlin-Frankfurt-Munster Group Trial NHL-BFM 90. Blood. 2001 Jun 15; 97(12):3699-3706. [PubMed: 11389005]

40. Bayle C, Charpentier A, Duchayne E, et al. Leukaemic presentation of small cell variant anaplastic large cell lymphoma: report of four cases. Br J Haematol. 1999 Mar; 104(4):680-688. [PubMed: 10192426]

41. Sandlund JT, Pui CH, Santana VM, et al. Clinical features and treatment outcome for children with CD30+ large-cell non-Hodgkin's lymphoma. J Clin Oncol. 1994 May; 12(5):895-898. [PubMed: 8164039]

42. Savage KJ, Harris NL, Vose JM, et al. ALK- anaplastic large-cell lymphoma is clinically and immunophenotypically different from both ALK+ ALCL and peripheral T-cell lymphoma, not otherwise specified: report from the International Peripheral T-Cell Lymphoma Project. Blood. 2008 Jun 15; 111(12):5496-5504. [PubMed: 18385450]

43. Laver JH, Kraveka JM, Hutchison RE, et al. Advanced-stage large-cell lymphoma in children and adolescents: results of a randomized trial incorporating intermediate-dose methotrexate and highdose cytarabine in the maintenance phase of the APO regimen: a Pediatric Oncology Group phase III trial. J Clin Oncol. 2005 Jan 20; 23(3):541-547. [PubMed: 15659500]

44. Brugieres L, Deley MC, Pacquement H, et al. CD30(+) anaplastic large-cell lymphoma in children: analysis of 82 patients enrolled in two consecutive studies of the French Society of Pediatric Oncology. Blood. 1998 Nov 15; 92(10):3591-3598. [PubMed: 9808552] 
45. Brugieres L, Le Deley MC, Rosolen A, et al. Impact of the methotrexate administration dose on the need for intrathecal treatment in children and adolescents with anaplastic large-cell lymphoma: results of a randomized trial of the EICNHL Group. J Clin Oncol. 2009 Feb 20; 27(6):897-903. [PubMed: 19139435]

46. Lowe EJ, Sposto R, Perkins SL, et al. Intensive chemotherapy for systemic anaplastic large cell lymphoma in children and adolescents: final results of Children's Cancer Group Study 5941. Pediatr Blood Cancer. 2009 Mar; 52(3):335-339. [PubMed: 18985718]

47. Reiter A, Schrappe M, Tiemann M, et al. Successful treatment strategy for Ki-1 anaplastic largecell lymphoma of childhood: a prospective analysis of 62 patients enrolled in three consecutive Berlin-Frankfurt-Munster group studies. J Clin Oncol. 1994 May; 12(5):899-908. [PubMed: 8164040]

48. Dunleavy K, Shovlin M, Pittaluga S, et al. DA-EPOCH Chemotherapy is Higly Effective in ALKPositive and ALK-negative ALCL: Results of a Prospective Study of PTCL Subtypes in Adults. Blood (ASH Annual Meeting Abstracts) 2011. 2011; 118:1618.

49. Sandlund JT, Pui CH, Roberts WM, et al. Clinicopathologic features and treatment outcome of children with large-cell lymphoma and the $t(2 ; 5)(p 23 ; q 35)$. Blood. 1994 Oct 15; 84(8):2467-2471. [PubMed: 7919366]

50. Reiter A, Schrappe M, Parwaresch R, et al. Non-Hodgkin's lymphomas of childhood and adolescence: results of a treatment stratified for biologic subtypes and stage--a report of the BerlinFrankfurt-Munster Group. J Clin Oncol. 1995 Feb; 13(2):359-372. [PubMed: 7844597]

51. Brugieres L, Pacquement H, Le Deley MC, et al. Single-drug vinblastine as salvage treatment for refractory or relapsed anaplastic large-cell lymphoma: a report from the French Society of Pediatric Oncology. J Clin Oncol. 2009 Oct 20; 27(30):5056-5061. [PubMed: 19738127]

52. Brugieres L, Quartier P, Le Deley MC, et al. Relapses of childhood anaplastic large-cell lymphoma: treatment results in a series of 41 children--a report from the French Society of Pediatric Oncology. Ann Oncol. 2000 Jan; 11(1):53-58. [PubMed: 10690387]

53. Cesaro S, Pillon M, Visintin G, et al. Unrelated bone marrow transplantation for high-risk anaplastic large cell lymphoma in pediatric patients: a single center case series. Eur J Haematol. 2005 Jul; 75(1):22-26. [PubMed: 15946306]

54. Woessmann W, Peters C, Lenhard M, et al. Allogeneic haematopoietic stem cell transplantation in relapsed or refractory anaplastic large cell lymphoma of children and adolescents--a BerlinFrankfurt-Munster group report. Br J Haematol. 2006 Apr; 133(2):176-182. [PubMed: 16611309]

55. Woessmann W, Zimmermann M, Lenhard M, et al. Relapsed or refractory anaplastic large-cell lymphoma in children and adolescents after Berlin-Frankfurt-Muenster (BFM)-type first-line therapy: a BFM-group study. J Clin Oncol. 2011 Aug 1; 29(22):3065-3071. [PubMed: 21709186]

56. Okeley NM, Miyamoto JB, Zhang X, et al. Intracellular activation of SGN-35, a potent anti-CD30 antibody-drug conjugate. Clin Cancer Res. 2010 Feb 1; 16(3):888-897. [PubMed: 20086002]

57. Bartlett NL, Younes A, Carabasi MH, et al. A phase 1 multidose study of SGN-30 immunotherapy in patients with refractory or recurrent CD30+ hematologic malignancies. Blood. 2008 Feb 15; 111(4):1848-1854. [PubMed: 18079362]

58. Younes A, Bartlett NL, Leonard JP, et al. Brentuximab vedotin (SGN-35) for relapsed CD30positive lymphomas. N Engl J Med. 2010 Nov 4; 363(19):1812-1821. [PubMed: 21047225]

59. Gingrich DE, Lisko JG, Curry MA, et al. Discovery of an orally efficacious inhibitor of anaplastic lymphoma kinase. J Med Chem. 2012 May 24; 55(10):4580-4593. [PubMed: 22564207]

60. Gambacorti-Passerini C, Messa C, Pogliani EM. Crizotinib in anaplastic large-cell lymphoma. N Engl J Med. 2011 Feb 24; 364(8):775-776. [PubMed: 21345110]

61. Hutchison RE, Laver JH, Chang M, et al. Non-anaplastic peripheral t-cell lymphoma in childhood and adolescence: a Children's Oncology Group study. Pediatr Blood Cancer. 2008 Jul; 51(1):29_ 33. [PubMed: 18300314]

62. Al Mahmoud R, Weitzman S, Schechter T, Ngan B, Abdelhaleem M, Alexander S. Peripheral Tcell lymphoma in children and adolescents: a single-institution experience. J Pediatr Hematol Oncol. 2012 Nov; 34(8):611-616. [PubMed: 23042011] 
63. Chott A, Augustin I, Wrba F, Hanak H, Ohlinger W, Radaszkiewicz T. Peripheral T-cell lymphomas: a clinicopathologic study of 75 cases. Hum Pathol. 1990 Nov; 21(11):1117-1125. [PubMed: 2227919]

64. Vose J, Armitage J, Weisenburger D. International peripheral T-cell and natural killer/T-cell lymphoma study: pathology findings and clinical outcomes. J Clin Oncol. 2008 Sep 1; 26(25): 4124-4130. [PubMed: 18626005]

65. Weisenburger DD, Savage KJ, Harris NL, et al. Peripheral T-cell lymphoma, not otherwise specified: a report of 340 cases from the International Peripheral T-cell Lymphoma Project. Blood. 2011 Mar 24; 117(12):3402-3408. [PubMed: 21270441]

66. Gordon BG, Warkentin PI, Weisenburger DD, et al. Bone marrow transplantation for peripheral Tcell lymphoma in children and adolescents. Blood. 1992 Dec 1; 80(11):2938-2942. [PubMed: 1450419]

67. Gordon BG, Weisenburger DD, Sanger WG, Armitage JO, Coccia PF. Peripheral T-cell lymphoma in children and adolescents: role of bone marrow transplantation. Leuk Lymphoma. 1994 Jun; 14(1-2):1-10. [PubMed: 7920214]

68. Wang ZY, Li YX, Wang WH, et al. Primary radiotherapy showed favorable outcome in treating extranodal nasal-type NK/T-cell lymphoma in children and adolescents. Blood. 2009 Nov 26; 114(23):4771-4776. [PubMed: 19812381]

69. Lee JY, Jang YD, Kim HK. The primary role of the otolaryngologist in managing pediatric sinonasal malignancies: an extranodal NK/T-cell lymphoma originating from the inferior turbinate mucosa of the nasal cavity. J Pediatr Hematol Oncol. 2008 May; 30(5):401-404. [PubMed: 18458579]

70. Ochenrider MG, Patterson DJ, Aboulafia DM. Hepatosplenic T-cell lymphoma in a young man with Crohn's disease: case report and literature review. Clin Lymphoma Myeloma Leuk. 2010 Apr; 10(2):144-148. [PubMed: 20371449]

71. Alonsozana EL, Stamberg J, Kumar D, et al. Isochromosome 7q: the primary cytogenetic abnormality in hepatosplenic gammadelta T cell lymphoma. Leukemia. 1997 Aug; 11(8):13671372. [PubMed: 9264394]

72. Jacobsen ED, Kim HT, Ho VT, et al. A large single-center experience with allogeneic stem-cell transplantation for peripheral T-cell non-Hodgkin lymphoma and advanced mycosis fungoides/ Sezary syndrome. Ann Oncol. 2011 Jul; 22(7):1608-1613. [PubMed: 21252059]

73. Medhi K, Kumar R, Rishi A, Kumar L, Bakhshi S. Subcutaneous panniculitislike T-cell lymphoma with hemophagocytosis: complete remission with BFM-90 protocol. J Pediatr Hematol Oncol. 2008 Jul; 30(7):558-561. [PubMed: 18797207] 


\section{Practice Points}

1. For most pediatric patients with T-LBL, ALL-type regimens with CNS chemotherapy prophylaxis are typically used.

2. Though the optimal therapy for pediatric ALCL has not been defined, anthracycline-based regimens that are used for aggressive B-cell lymphoma are very effective, especially for patients with ALK positive disease, which compromises the majority of patients.

3. Albeit very limited experience, aggressive approaches that include autologous and allogeneic transplantation appear to be very effective for patients with relapsed T-LBL and ALCL. 


\section{Research Agenda}

1. NOTCH1 activation appears to be important in the pathogenesis of T-ALL and T-LBL and strategies that target NOTCH1 upregulation are being tested in vitro. Targeting mTOR is also under investigation

2. In ALCL, in adults, brentuximab vedotin - an antibody-drug conjugate directed against CD30 - has been successfully used in adults with relapsed ALCL but has not been tested in children. Also, crizotinib, which directly inhibits ALK, has shown promise in early trials. 


\section{Summary}

Pediatric $\mathrm{T}$ and NK cell lymphomas are a rare and complicated group of diseases that arise from lymphoblasts committed to the T-cell lineage or mature T and NK-cell subsets. Significant advances have been made in the treatment of these disorders over the past 30 years and most pediatric patients with these diagnoses have a good outcome with current therapeutic approaches. As with adult T and NK cell disorders, with the exception of ALCL, little is known about the molecular pathogenesis of these diseases - this is in contrast to B-cell lymphomas, whose biology is much better elucidated. However, novel approaches to treatment such as targeting CD30 and the ALK protein are in development and the recognition that NOTCH1 activation and mTOR pathways are important in diseases like T-LBL offer the promise of novel agent development for these diseases. 
Table 1

Pivotal trials in treating T-LBL

\begin{tabular}{|l|l|l|l|l|}
\hline Group & Regimen & $\mathbf{n}$ & Patient population & Outcome \\
\hline CCG-551 17 & $\begin{array}{l}\text { LSA2L2 (10 drug regimen } \\
\text { with RT to bulky sites) }\end{array}$ & 124 & $\begin{array}{l}\text { All had disseminated disease. Included CNS } \\
\text { disease }\end{array}$ & $\begin{array}{l}\text { EFS and OS of 64\% and 67\% } \\
\text { at 5 years }\end{array}$ \\
\hline BFM-90 & $\begin{array}{l}\text { ALL-type therapy; most } \\
\text { received CRT }\end{array}$ & 105 & $\begin{array}{l}\text { All stages of disease but most had stages III } \\
\text { or IV. Included CNS disease. }\end{array}$ & EFS of 90\% at 5 years \\
\hline BFM-95 ${ }^{18}$ & $\begin{array}{l}\text { ALL-type therapy. No } \\
\text { CRT }\end{array}$ & 156 & CNS negative stage III and IV disease & EFS of $82 \%$ at 5 years \\
\hline EORTC-CLG-588819 & All-type therapy. No CRT & 119 & $\begin{array}{l}\text { All stages. Small percentage were CNS } \\
\text { positive }\end{array}$ & EFS of 77\% at 6 years \\
\hline St. Jude NHL 137 & $\begin{array}{l}\text { ALL-type therapy. No } \\
\text { CRT }\end{array}$ & 41 & $\begin{array}{l}\text { All had stage III or IV disease. 10\% had CNS } \\
\text { involvement }\end{array}$ & EFS and OS of $83 \%$ and $90 \%$ \\
\hline
\end{tabular}


Table 2

Pivotal trials in treating ALCL

\begin{tabular}{|l|l|l|l|l|}
\hline Group & Regimen & $\mathbf{n}$ & Patient population & Outcome \\
\hline BFM-90 & Short pulse B-NHL therapy & 89 & All stages. Most had stage III or IV & $\begin{array}{l}\text { EFS of 76\% at 5 years. Stage I and II } \\
\text { resected patients had an EFS of 100\% }\end{array}$ \\
\hline CCG-594146 & $\begin{array}{l}\text { Multi-agent regimen with } \\
\text { induction, consolidation and } \\
\text { maintenenance }\end{array}$ & 86 & $\begin{array}{l}\text { All patients had non-localized } \\
\text { disease }\end{array}$ & EFS of 68\% and OS of $80 \%$ at 5 years \\
\hline EICNHL 45 & $\begin{array}{l}\text { Multi-agent regimen. } \\
\text { Randomized to different } \\
\text { administration schedules of } \\
\text { MTX }\end{array}$ & 352 & All stages. Most had stage III or IV & $\begin{array}{l}\text { EFS of 74\% and 75\% at 5 years. No } \\
\text { advantage of more toxic MTX schedule. }\end{array}$ \\
\hline
\end{tabular}

